\title{
Identifying the Blue Economy Global Epistemic Community
}

\author{
Alejandro Vega-Muñoz ${ }^{1, *(\mathbb{D})}$, Guido Salazar-Sepúlveda ${ }^{2} \mathbb{D}$ and Nicolás Contreras-Barraza ${ }^{3, *(D)}$ \\ 1 Public Policy Observatory, Universidad Autónoma de Chile, Providencia 7500912, Chile \\ 2 Departamento de Ingeniería Industrial, Facultad de Ingeniería, Universidad Católica de la Santísima \\ Concepción, Concepción 4090541, Chile; gsalazar@ucsc.cl \\ 3 Facultad de Economía y Negocios, Universidad Andres Bello, Viña del Mar 2531015, Chile \\ * Correspondence: alejandro.vega@uautonoma.cl (A.V.-M.); nicolas.contreras@unab.cl (N.C.-B.)
}

check for

updates

Citation: Vega-Muñoz, A.;

Salazar-Sepúlveda, G.;

Contreras-Barraza, N. Identifying the Blue Economy Global Epistemic Community. Water 2021, 13, 3234. https://doi.org/10.3390/w13223234

Academic Editors: Robert C. Burns and Danielle Schwarzmann

Received: 31 October 2021

Accepted: 11 November 2021

Published: 15 November 2021

Publisher's Note: MDPI stays neutral with regard to jurisdictional claims in published maps and institutional affiliations.

Copyright: (c) 2021 by the authors. Licensee MDPI, Basel, Switzerland. This article is an open access article distributed under the terms and conditions of the Creative Commons Attribution (CC BY) license (https:/ / creativecommons.org/licenses/by/ $4.0 /)$.

\begin{abstract}
The following article aims to identify the characteristics of the epistemic community of Blue Economy researchers, through the description of its scientific production, its special organization and clustering. The information was examined using bibliometric techniques on 302 research works using the Web of Science databases (JCR) between 2013 and 2021. At the same time, VOSviewer software was used to represent the relationships metrically and visually between the data and metadata. A set of research works is reviewed which relates environmental conservation and its implication in the development of the territory, and the relationship between technology and the improvement of ocean management, to highlight those state interventions where benefits are generated for the population or where there is an important challenge for improvement.
\end{abstract}

Keywords: environmental; coastal; Blue Economy; politics; aquaculture; energy

\section{Introduction}

Epistemic communities, based on knowledge of societies, are constituted by a group of people who periodically develop agreements on a problem and its possible solution [1-5], becoming a network of specialists who are recognized for their experience, competencies, and mastery of a thematic area [4-8].

According to Haas [4] epistemic communities share certain characteristics such as; (1) The sharing of a set of norms, principles, and beliefs, which provide a value-based justification for the social action of community members; (2) Attachment to shared causal beliefs, which are derived from their analysis of practices that lead to or contribute to a core set of problems in their domain and which then serve as the basis for possible policy actions and desired outcomes; (3) Internally defined intersubjective criterion validity mechanisms for weighing and validating knowledge in the domain of their expertise; and (4) The development of common practices associated with a set of problems addressed by their professional competence.

The following research aims to identify, describe, and unveil the epistemic communities of the Blue Economy with respect to their areas of scientific production, provenance, cooperation networks and current trends under study.

The Blue Economy is a strategy that several countries in the world are participating in to support and protect the planet's water resources in a sustainable way, dealing with two fronts: on the one hand, economic development and growth, and on the other hand, the protection of ocean resources [9,10]. According to the EU Blue Economy Report 2021 [11] (p. 2): "Blue Economy encompasses all sectoral and cross-sectoral economic activities based on or related to the oceans, seas, and coasts:

- Marine-based activities: include the activities undertaken in the ocean, sea, and coastal areas, such as Marine living resources (capture fisheries and aquaculture), Marine minerals, Marine renewable energy, Desalination, Maritime transport, and Coastal tourism. 
- Marine-related activities: activities which use products and/or produce products and services from the ocean or marine-based activities like seafood processing, biotechnology, Shipbuilding and repair, Port activities, technology and equipment, digital services, etc."

In addition to several studies, the Blue Economy would increase the long-term benefits of the sustainable use of marine resources by identifying profitable sectors and activities related to the oceans. These benefits are valued at trillions of dollars per year globally, support hundreds of millions of jobs, and contribute to all countries, where the coastal zo-ne is home to half of the world's population [12-14].

To achieve the above, sustainable economic development must be accompanied using tools to measure the diversification of products and services, such as food production, the use of emerging energies, marine biotechnology, seabed mining, and tourism and recreation, based on a political agenda that focuses on marine governance strategies that stimulate the combination of marine industries in the most promising areas, integrating economic indicators to measure the Blue Economy [15-26].

On the other hand, management policies for ocean sustainability, market-oriented price mechanisms, learning from the political evolution of advanced countries in these matters and opening the market to foreign investors will promote the effectiveness of ocean governance policies and further strengthen the growth of these countries [10,27].

Government challenges include improving the management and governance of marine resources, implementing a public-private partnership platform in conjunction with academia for the incorporation of innovation in marine technology, training young talent, addressing the cultural heritage of marine communities, and promoting blended finance as a way to enhance biotechnology markets [28-33], considering the reorientation towards the creation of blue communities. These communities should consider social, cultural, and environmental factors that will provide balanced economic growth [34], and incorporating social innovation investment policies to avoid unequal distribution of benefits and potential environmental damage [33,35].

It is important to emphasize that a nation's strategic vision in the implementation of the Blue Economy must integrate coastal organizations to advance the sustainable management of marine ecosystems and resources [18], environmental concerns, habitat destruction, water pollution, eutrophication, biotic depletion, ecological effects, and disease outbreaks make it essential to incorporate new regulations. Stronger legislation that includes guidelines on the Blue Economy in the field of sustainable economic development could avoid socio-ecological conflicts with the population [16,35-38].

An example of this is the tourism industry, where cruise ships represent $1.6 \%$ of the total number of tourists in the world, unfortunately being a source of pollution due to the spillage of pollutants or the transfer of invasive species to other areas [39,40].

However, there are many other examples such as plastic parts, including microplastics and nanoplastics, due to their propagation in ecosystems and their ability to interact with biological systems or the textile industry, with the disposal of effluents in rivers and oceans affecting coral reefs or critical habitats such as seagrasses, which constitute a po-tential threat to recreational activities-especially diving. This is why the incorporation of the fundamentals of the Blue Economy, which promote sustainable development by minimizing freshwater consumption, organic pollution and chemical contamination in addition to strengthening tourism from coastal communities, enhancing the marketing of their products, the combination of their landscapes, ecological cultures, and recreational fishing, among others, is important $[37,39,41-45]$.

On the other hand, there are new initiatives that seek to enhance the benefits provided by nature in coastal areas; among the most promising areas is the offshore wind industry as a method for reducing $\mathrm{CO}_{2}$ emissions, air pollution and carbon mitigation [46-48]. Geographical location, energy system durability and energy demand are the key elements for its development [17,49-51].

Another area that stands out for its expansion is aquaculture, which is influenced by the growing global demand for fish, the decline of natural fisheries, its contribution to 
human nutrition, food security and improvement of the welfare of the coastal population in general, but which may be affected if it focuses only on increasing production $[16,37,52-58]$. For this reason, progress in aquaculture legislation must face the challenge of incorporating a sociological perspective, the distribution of equitable benefits to the community to achieve equitable aquaculture development and of clarifying the region's expectations [36,52].

Finally, it is important to note the importance of updating maritime policies around the world, which should include the guidelines of the sustainability development goals, (SDGs) such as: SDG 7 (affordable and clean energy), SDG 8 (decent work and economic growth) or SDG 10 (reduce inequalities), SDG 12 (responsible production and consumption), SDG 13 (climate action), and SDG 14 (undersea life), which under the philosophy of a Blue Economy would allow the better management, development and use of marine resources over short-term economic growth [59-63].

\section{Methods}

A set of articles has been extracted from the Web of Science indexed Social Science Citation Index and Science Citation Index Expanded, with the search vector (TS = (blue NEAR/ 0 economy) [64]. The annual growth of publications on the extracted set of documents is evaluated based on Price Law $[65,66]$, identifying a possible exponential growth of science, as a function of the published articles per year and the adjustment of the determination coefficient (R-squared) to an exponential growth rate. Then, Bradford's Law gives 3 article subsets that approximate one third of the manuscripts each. It establishes a hierarchy of journals and identifies the journal nucleus where scientific production is concentrated [67] and, additionally, 2 expansion journal areas, which should grow geometrically. Subsequently, a set of prolific authors is identified with exceptional scientific production levels in the subject of the Blue Economy, according to Lotka's Law [68]-a number that must at least approach the square root of the total authors contributing to the set of articles analyzed [68] — before characterizing them according to the data and metadata extracted in each record and presenting them in terms of author affiliations and documented scientific production with VOSviewer [69].

\section{Results}

The 302 articles on the Blue Economy identified are in line with an exponential growth over time, with an $\mathrm{R}^{2}$ of $96.1 \%$ (between 2013 and 2021, see Supplementary Material Table S1), which allows us to establish the existence of a global critical mass of researchers interested in increasing the body of knowledge on this topic. In addition to this, the frequency of distribution in the JCR-WoS journals of the 302 articles is presented in Figure 1, where we can see that only one article on the Blue Economy has been published in 88 journals.

Given this diversity of journals, from those that have published only one article on the subject, to one that has published 47 articles, it is necessary to establish concentration levels to identify where the discussion on the Blue Economy is most intense-as shown in Table 1.

Table 1. Publications on Blue Economy by Bradford's zones between 2013 and 2022.

\begin{tabular}{|c|c|c|c|c|c|c|c|}
\hline \multirow{2}{*}{$\begin{array}{c}\text { Zone } \\
\text { Nucleus }\end{array}$} & \multicolumn{2}{|c|}{$\begin{array}{l}\text { Number of } \\
\text { Articles (\%) }\end{array}$} & \multicolumn{2}{|c|}{$\begin{array}{c}\text { Journals } \\
\text { (\%) }\end{array}$} & \multirow[t]{2}{*}{$\begin{array}{c}\text { Bradford } \\
\text { Multipliers }\end{array}$} & \multicolumn{2}{|c|}{$\begin{array}{c}\text { Journals } \\
\text { (Theoretical Serie) }\end{array}$} \\
\hline & 109 & $(36 \%)$ & $a=4$ & $(3 \%)$ & & $1 \cdot a$ & 4 \\
\hline Zone 1 & 105 & $(35 \%)$ & 37 & $(29 \%)$ & 9.3 & $a \cdot n$ & 23 \\
\hline Zone 2 & 88 & $(29 \%)$ & 88 & $(68 \%)$ & 2.4 & $a \cdot n^{2}$ & 135 \\
\hline \multirow[t]{2}{*}{ Total } & \multirow{2}{*}{\multicolumn{2}{|c|}{302}} & \multirow{2}{*}{\multicolumn{2}{|c|}{129 * }} & $\mathrm{n}=5.8$ & & $162 *$ \\
\hline & & & & & & $\%$ error $=$ & $-26.0 \%$ \\
\hline
\end{tabular}

${ }^{*}$ Real and theoretical value, incorporated for percentage error calculation. 


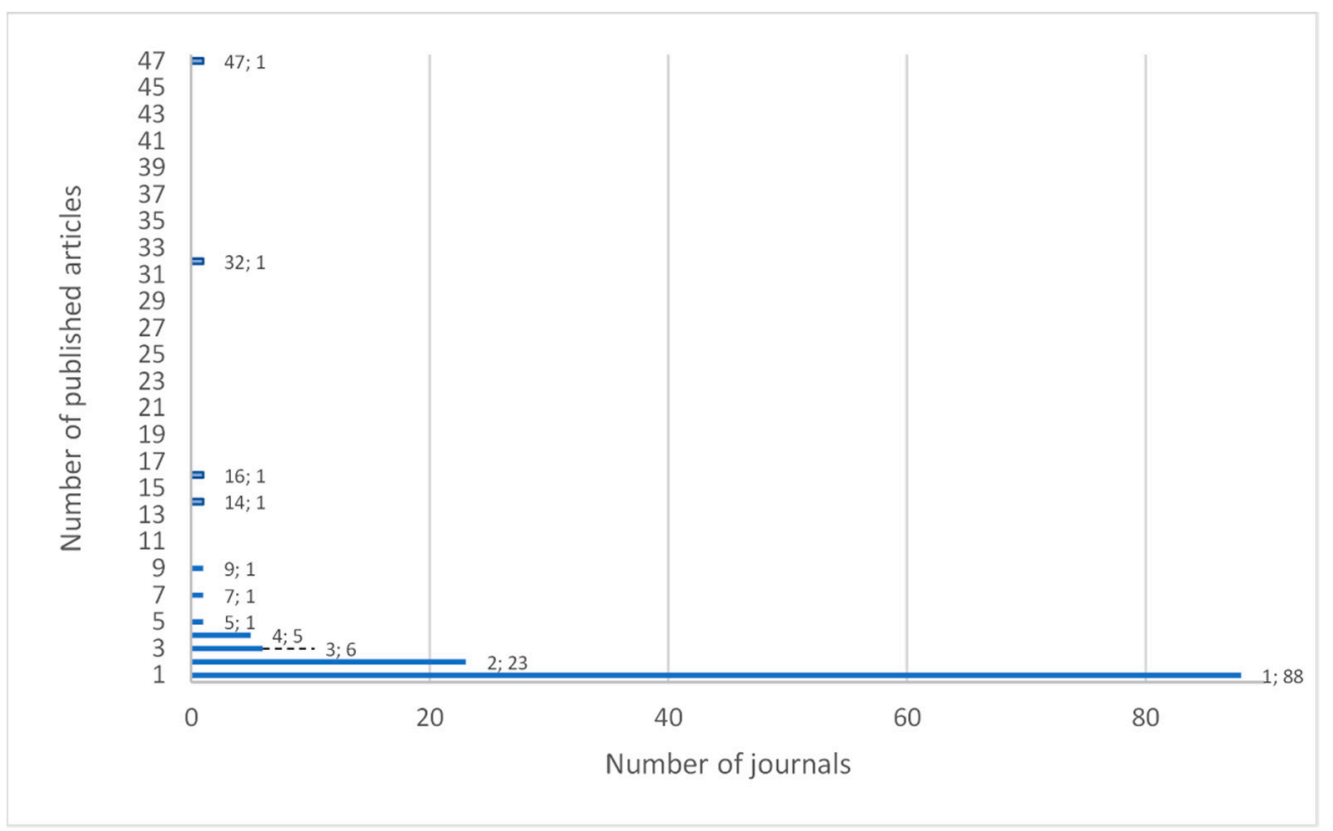

Figure 1. Blue Economy publications frequency distribution in JCR-WoS journals.

The Bradford zone calculation is reported, as indicated in Table 1. Given a core zone $a=4$ and a mean multiplier $n=5.8$, Equation (1) for the geometric series summation of Bradford $\left(S_{S B}\right)$ is:

$$
S_{S B}=\sum_{i=1}^{3}\left(a \times n^{i-1}\right)=4+23+135=162
$$

with an error percentual $\left(\varepsilon_{p}\right)$ margin in Equation (2):

$$
\varepsilon_{p}=\left(\frac{(\text { Real }- \text { Estimated })}{\text { Real }}\right) \times 100=\left(\frac{(129-162)}{129}\right) \times 100=-26 \%
$$

This level of error is due to the unusually high number of journals in which only a couple articles on the Blue Economy have been published ( 23 of 37 journals in zone 1, increasing the Bradford multiplier in this level to 9.3). The four journals that belong to the Bradford core journals are: Marine Policy, Frontiers in Marine Science, Sustainability, and Ocean and Coastal Management. Details of which are given in Table 2:

Table 2. Journals in the Bradford's nucleus with articles on the Blue Economy.

\begin{tabular}{ccccc}
\hline Journal & Article & WoS Categories & $\begin{array}{c}\text { Journal Impact } \\
\text { Factor (2020) }\end{array}$ & $\begin{array}{c}\text { Best } \\
\text { Quartile }\end{array}$ \\
\hline Mar. Pol. & 47 & $\begin{array}{c}\text { Environmental Studies; } \\
\text { International Relations }\end{array}$ & 4.173 & Q1 \\
\hline Front. Mar. Sci. & 32 & $\begin{array}{c}\text { Environmental Sciences; } \\
\text { Marine \& Freshwater Biology }\end{array}$ & 4.912 & Q1 \\
\hline Sustainability & 16 & $\begin{array}{c}\text { Green \& Sustainable } \\
\text { Science \& Technology; } \\
\text { Environmental Sciences; } \\
\text { Environmental Studies }\end{array}$ & 3.251 & $\mathrm{Q} 2$ \\
\hline Ocean Coastal Manage. & 14 & Oceanography; Water Resources & 3.284 & $\mathrm{Q}$ \\
\hline
\end{tabular}

With respect to the prolific authors, we have identified those who have managed to publish 3 or more articles related to this topic, resulting in 27 authors grouped into 10 clusters, as shown in Figure 2. 


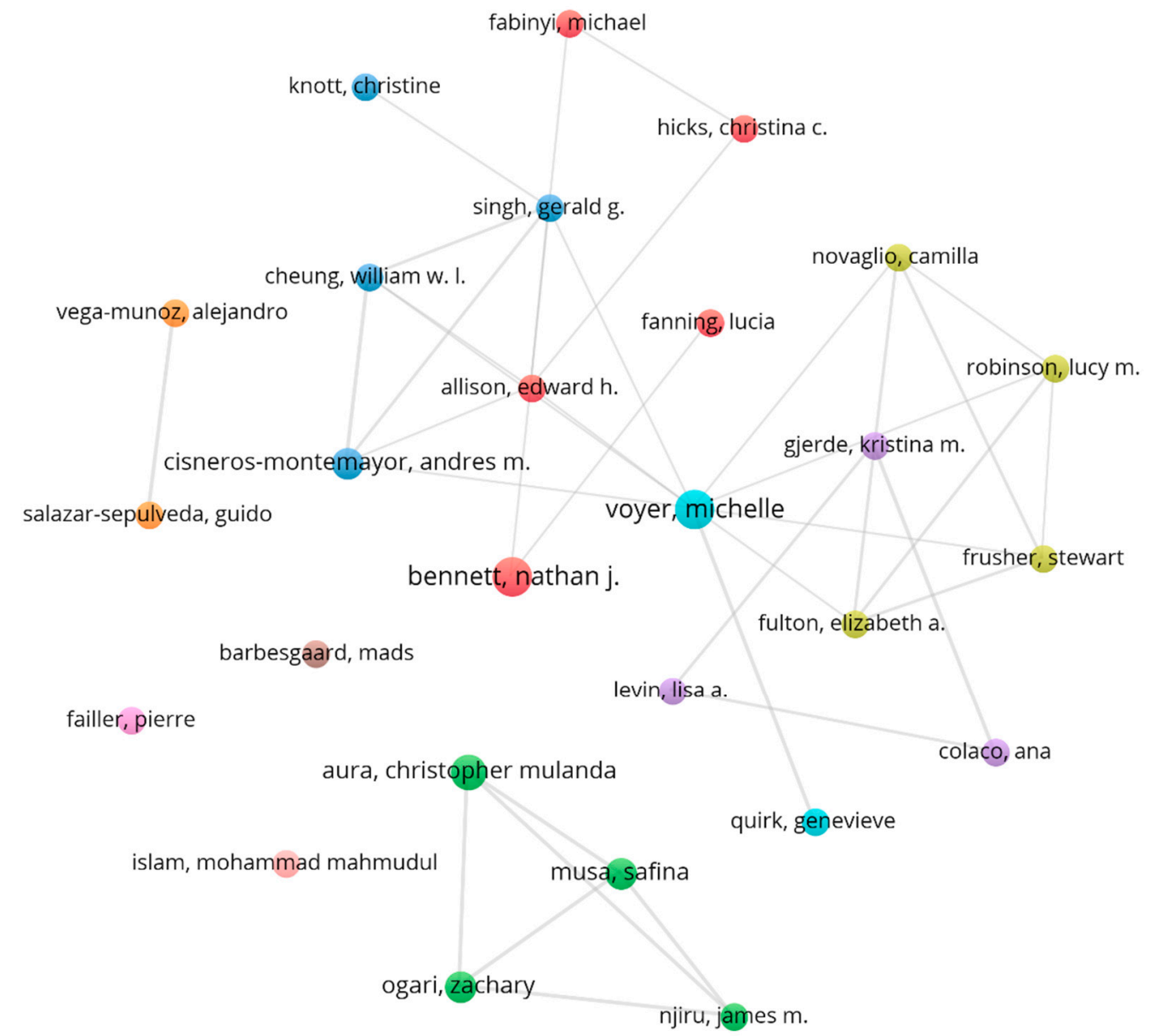

Figure 2. Cluster prolific authors on Blue Economy.

The details of this figure are shown in Table 3, adding information about their affiliation, affiliation country, published articles (considering the most prolific author of the group), and the journal where their production is concentrated.

Table 3 shows the highest participation of Australia, found in three clusters/nodes, the United Kingdom in two, and the USA in two. On the other hand, eight of the clusters published in the four journals of the Bradford nucleus, with a majority presence in Mar. Pol., in which five of the ten clusters/nodes published a total of six articles, followed by Front. Mar. Sci. with three publishing clusters/nodes and a total of five articles; in the case of Sustainability, it only received publications from cluster 7 (orange), with authors from Chile. In general, the 10 clusters show a wide thematic diversity, which is shown in a concentrated manner in Figure 3, for the 302 articles extracted. 
Table 3. Cluster prolific authors on Blue Economy and data/metadata in co-authoring published articles.

\begin{tabular}{|c|c|c|c|c|c|c|c|}
\hline Cluster/Node & Authors & Affiliations & Country Affiliation & Number of Articles & $\begin{array}{l}\text { Concentration } \\
\text { Journal } \\
\text { (in NB) }\end{array}$ & Keywords Plus & $\begin{array}{l}\text { Authors } \\
\text { Keywords }\end{array}$ \\
\hline $\begin{array}{c}1 \\
\text { Red }\end{array}$ & $\begin{array}{l}\text { Allison, E. H. } \\
\text { Bennett, N. J. } \\
\text { Fabinyi, M. } \\
\text { Fanning, L. } \\
\text { Hicks, C. C. }\end{array}$ & $\begin{array}{l}\text { Univ Lancaster (UK), } \\
\text { Stanford Univ (USA), } \\
\text { Univ Technol Sydney } \\
\text { (AU); Univ Washington } \\
\text { (USA); James Cook Univ } \\
\text { (AU); Univ British } \\
\text { Columbia (CA); } \\
\text { Stanford Univ (CA); } \\
\text { Dalhousie Univ (CA); } \\
\text { WorldFish (MY) }\end{array}$ & $\begin{array}{c}\text { Australia (AU), } \\
\text { Malaysia (MY), } \\
\text { United Kingdom (UK, } \\
\text { England), USA }\end{array}$ & 3 & $\begin{array}{l}\text { Front. Mar. Sci. (2) } \\
\text { Mar. Pol. (1) }\end{array}$ & $\begin{array}{l}\text { Aquaculture; Climate-Change; } \\
\text { Conservation (3); Decision; Ecological } \\
\text { Vulnerability; Ecosystem-Based } \\
\text { Management; Enclosure; Fish; } \\
\text { Fisheries Management; Herring } \\
\text { Fisheries; Human-Rights; Impacts; } \\
\text { Insights; Knowledge; Livelihoods (2); } \\
\text { Management; Marine Protected Areas; } \\
\text { Natural-Resource Management; } \\
\text { Neoliberalism; Peoples; Perception; } \\
\text { Poverty; Privatization; Provide; Rights; } \\
\text { Social-Science; Voluntary Guidelines }\end{array}$ & $\begin{array}{l}\text { Blue economy (2); Blue Growth; } \\
\text { Canada; Coastal communities; } \\
\text { conservation; development; economic, } \\
\text { ecosystem management; Fisheries; } \\
\text { Human-rights; Indigenous } \\
\text { communities; Marine conservation; } \\
\text { Marine spatial planning; Ocean } \\
\text { governance (2); Resource access; risk } \\
\text { analysis; risk management; } \\
\text { social-ecological systems; Spatial } \\
\text { access; sustainability science }\end{array}$ \\
\hline $\begin{array}{c}2 \\
\text { Blue }\end{array}$ & $\begin{array}{l}\text { Cheung, W. W. L. } \\
\text { Cisneros-Montemayor, A. M. * } \\
\text { Knott, C. } \\
\text { Singh, G. G. }\end{array}$ & $\begin{array}{l}\text { Univ British Columbia } \\
\text { (CA); Mem Univ } \\
\text { Newfoundland (CA) }\end{array}$ & Canada (CA) & 4 & Mar. Pol. (2) & $\begin{array}{l}\text { Blue Economy (2); Climate Change; } \\
\text { Ecosystem Services; Fisheries } \\
\text { Management; Just Transitions; } \\
\text { Minimum Living Wage; Policy } \\
\text { Integration; Social Equity; } \\
\text { Sustainable Livelihoods }\end{array}$ & $\begin{array}{l}\text { Adaptation; Carbon Sequestration; } \\
\text { Coastal; Ecotourism; Fisheries Policy; } \\
\text { Global Ocean; Lessons; Management; } \\
\text { Marine Protected Areas; Mitigation } \\
\text { Hierarchy; Products; Reserves; Social } \\
\text { Impacts; Trade-Offs; Wind Energy }\end{array}$ \\
\hline $\begin{array}{c}3 \\
\text { Yellow }\end{array}$ & $\begin{array}{c}\text { Frusher, S. } \\
\text { Fulton, E. A. } \\
\text { Novaglio, C. } \\
\text { Robinson, L. M. }\end{array}$ & $\begin{array}{l}\text { Ctr Marine Socioecol } \\
\text { (AU); Univ Tasmania } \\
\text { (AU); CSIRO (AU); Univ } \\
\text { Western Australia (AU) }\end{array}$ & Australia (AU) & 3 & Front. Mar. Sci. (1) & $\begin{array}{l}\text { Blue Economy (2); Blue Growth; } \\
\text { Conflict Resolution; Conservation; } \\
\text { Decade of The Ocean; Equity (2); } \\
\text { Future Seas; Future Studies; Global } \\
\text { Change; Global Scenarios; Industry; } \\
\text { Interdisciplinary Research; Marine } \\
\text { Resources; Marine\&\#160; } \\
\text { Multidisciplinary; Ocean; Sovereignty; } \\
\text { Sustainable Development Goals; UN } \\
\text { Sustainable Development Goals }\end{array}$ & Blue Growth; Foresight \\
\hline $\begin{array}{c}4 \\
\text { Green }\end{array}$ & $\begin{array}{l}\text { Aura, C. M. } \\
\text { Musa, S. } \\
\text { Njiru, J. M. } \\
\text { Ogari, Z. }\end{array}$ & $\begin{array}{c}\text { Kenya Marine \& } \\
\text { Fisheries Res Inst (KE); } \\
\text { Kisii Univ. (KE) }\end{array}$ & Kenya (KE) & 5 & 0 & $\begin{array}{l}\text { Aquatic Resources; Blue Economy (4); } \\
\text { Cage Culture; Conflicts; Criteria; } \\
\text { Critical Habitats } \\
\text { Fisheries (2); Food; Information and } \\
\text { Communication Technology; Inland; } \\
\text { Integrity; Interventions; Lake Victoria; } \\
\text { Lake-Fishery; Landing Site; } \\
\text { Management; Mapping; Market; } \\
\text { Nutrition; Post-Harvest; Small-Scale; } \\
\text { Socio-economics }\end{array}$ & $\begin{array}{l}\text { Fisheries; Food; Gulf; Inshore; Lake } \\
\text { Victoria (2); Lates-Niloticus; } \\
\text { Management (2); Nile Perch; Offshore } \\
\text { Waters; Quality; Shelf-Life; Tilapia } \\
\text { Oreochromis-Niloticus }\end{array}$ \\
\hline
\end{tabular}


Table 3. Cont

\begin{tabular}{|c|c|c|c|c|c|c|c|}
\hline Cluster/Node & Authors & Affiliations & Country Affiliation & Number of Articles & $\begin{array}{l}\text { Concentration } \\
\text { Journal } \\
\text { (in NB) }\end{array}$ & Keywords Plus & $\begin{array}{l}\text { Authors } \\
\text { Keywords }\end{array}$ \\
\hline $\begin{array}{c}5 \\
\text { Purple }\end{array}$ & $\begin{array}{l}\text { Colaco, Ana } \\
\text { Gjerde, Kristina M. } \\
\text { Levin, Lisa A. }\end{array}$ & $\begin{array}{c}\text { IMAR (PT); Int Union } \\
\text { Conservat Nat (USA); } \\
\text { MARE (PT); Middlebury } \\
\text { Inst Int Studies } \\
\text { Monterey (USA); Univ } \\
\text { Acores (PT); Univ Calif } \\
\text { San Diego (USA); } \\
\text { Wycliffe Management } \\
\text { Ltd. (PL) }\end{array}$ & $\begin{array}{l}\text { Polonia (PL); Portugal } \\
\text { (PT); USA }\end{array}$ & 3 & $\begin{array}{l}\text { Front. Mar. Sci. (2) } \\
\text { Mar. Pol. (1) }\end{array}$ & $\begin{array}{c}\text { Biodivercity; Biodiversity; Blue } \\
\text { Economy (2); Deep Sea (2); } \\
\text { Environmental Impact Assessment; } \\
\text { Essential Ocean Variables (2); } \\
\text { Management Systems; Mitigation; } \\
\text { Monitoring; Ocean Decade; Ocean } \\
\text { Observation; Ocean Sensors; Seabed } \\
\text { Mining Industry }\end{array}$ & $\begin{array}{c}\text { Antarctic Bottom Water; Benthic } \\
\text { Invertebrates; Biogeographic } \\
\text { Classification; Challenger Deep; } \\
\text { Challenges; Clarion-Clipperton Zone; } \\
\text { Community Structure; } \\
\text { Continental-Slope; Corporate; } \\
\text { Demersal Fishes; Environmental } \\
\text { Impacts; Framework; } \\
\text { High-Throughput; } \\
\text { Hydrothermal-Vent; Impact } \\
\text { Assessment; Izu-Ogasawara Trench; } \\
\text { Latitudinal Gradients; Lessons; } \\
\text { Mediterranean Sea; NE Atlantic; } \\
\text { North-Atlantic; Northeast Pacific; } \\
\text { Norway; Offshore Oil; } \\
\text { Oxygen-Minimum Zones; Polymetallic } \\
\text { Nodules; Species-Diversity; } \\
\text { Sustainability; Systems }\end{array}$ \\
\hline $\begin{array}{c}6 \\
\text { Light blue }\end{array}$ & $\begin{array}{l}\text { Quirk, G. } \\
\text { Voyer, M. }\end{array}$ & Univ Wollongong (AU) & Australia (AU) & 3 & $\begin{array}{l}\text { Ocean Coastal } \\
\text { Manage. (1) }\end{array}$ & $\begin{array}{l}\text { Blue Economy (3); Blue Growth; } \\
\text { Oceans Governance; Policy coherence } \\
\text { (2); Policy coordination; SDGs (2); } \\
\text { Sustainable Development Goals; } \\
\text { Timor Leste }\end{array}$ & $\begin{array}{l}\text { Sustainable Development; Marine; } \\
\text { Growth; Coastal; Carbon }\end{array}$ \\
\hline $\begin{array}{c}8 \\
\text { Brown }\end{array}$ & Barbesgaard, M. & $\begin{array}{l}\text { Transnatl Inst (NL); } \\
\text { Lund Univ (SE) }\end{array}$ & $\begin{array}{l}\text { Netherlands (NL); } \\
\text { Sweden (SE) }\end{array}$ & 3 & Mar. Pol. (1) & $\begin{array}{l}\text { Aquaculture; Blue economy (2); Blue } \\
\text { growth; Deep sea mining; Deep-sea } \\
\text { mining (DSM); Environmental } \\
\text { governance; For-profit conservation; } \\
\text { Geopolitics; Impact investing; Marine } \\
\text { protected areas; } \\
\text { Maritime geography; Ocean grabbing } \\
\text { (2); Oil and gas; Political economy; } \\
\text { SIDS; UNCLOS }\end{array}$ & $\begin{array}{c}\text { Accumulation; Biodiversity } \\
\text { Conservation; Challenges; } \\
\text { Climate-Change; Conservation; } \\
\text { Economy; Fisheries (2); Global Land; } \\
\text { Governance; Governmentality; Green } \\
\text { Economy; Growth; Impacts; } \\
\text { Management; Marine; Oil; Outcomes; } \\
\text { People; Political-Economy; Sea (2); } \\
\text { Selling Nature; Services; Sustainable } \\
\text { Development (2) }\end{array}$ \\
\hline
\end{tabular}


Table 3. Cont.

\begin{tabular}{|c|c|c|c|c|c|c|c|}
\hline Cluster/Node & Authors & Affiliations & Country Affiliation & Number of Articles & $\begin{array}{c}\text { Concentration } \\
\text { Journal } \\
\text { (in NB) } \\
\end{array}$ & Keywords Plus & $\begin{array}{l}\text { Authors } \\
\text { Keywords }\end{array}$ \\
\hline $\begin{array}{c}9 \\
\text { Fuchsia }\end{array}$ & Failler, $P$. & Univ Portsmouth (UK) & $\begin{array}{l}\text { United Kingdom } \\
\text { (UK, England), }\end{array}$ & 3 & 0 & $\begin{array}{c}\text { Africa; Blue Carbon \& Ecosystem } \\
\text { Services; Blue Economy (2); Blue } \\
\text { Economy Development; Climate } \\
\text { Resilience; Coastal and Marine } \\
\text { Tourism; Coastal Marine Habitats; } \\
\text { Collaboration; Constraints; } \\
\text { Development; Environment; Habitat } \\
\text { Functionality; Infrastructure; Large } \\
\text { Marine Ecosystems; Large Marine } \\
\text { Ecosystems (LMES); Mariculture; } \\
\text { Nature's Contributions to } \\
\text { People; Potential }\end{array}$ & $\begin{array}{l}\text { Benefits; Biodiversity; Examples; } \\
\text { Forests; Impact; Issues; Management; } \\
\text { Progress; Protection; Vulnerability }\end{array}$ \\
\hline $\begin{array}{l}10 \\
\text { Pink }\end{array}$ & Islam, M. M. & Sylhet Agr Univ (BD) & Bangladesh (BD) & 3 & $\begin{array}{l}\text { Mar. Pol. (1) } \\
\text { Ocean Coastal } \\
\text { Manage. (1) }\end{array}$ & $\begin{array}{c}\text { Bangladesh; Bay of Bengal (2); Blue } \\
\text { Economy (2); Blue Growth; Coastal } \\
\text { and marine; conservation; Economics; } \\
\text { Governance; Legal framework; Marine } \\
\text { living resources; management; Marine } \\
\text { resources; SDG14; SDGs (2); } \\
\text { Sustainable development goals (SDGs) }\end{array}$ & $\begin{array}{l}\text { Coastal; Coastal Fisheries; Impacts; } \\
\text { Issues; Marine Fisheries; Philippines; } \\
\text { Protected Areas; Science }\end{array}$ \\
\hline
\end{tabular}




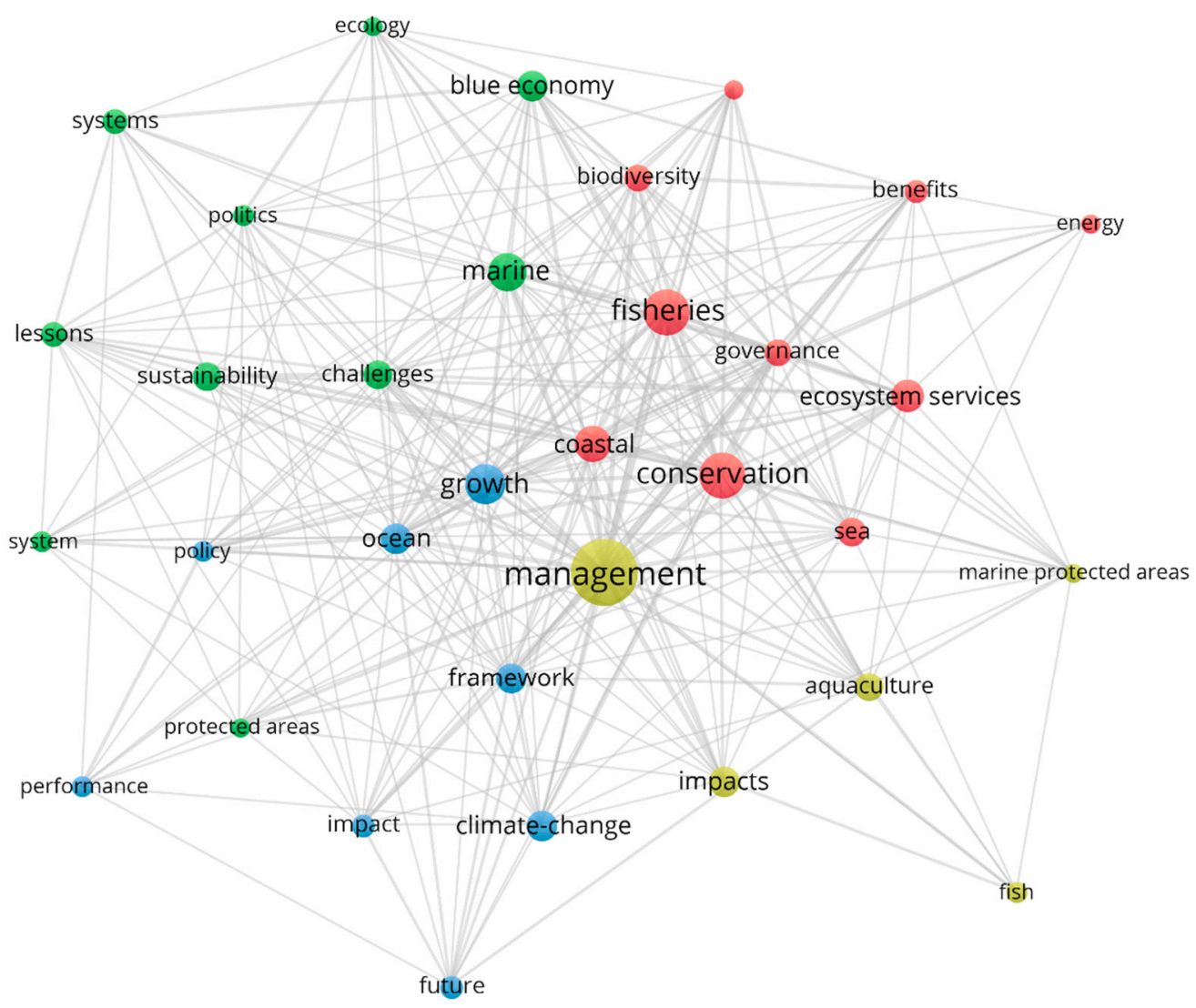

Figure 3. Outstanding keywords plus on Blue Economy.

Strong concepts are highlighted in relation to environmental conservation and its implication in the development of marine and coastal territory, the relationship between technological aspects and the improvement of the management of the oceans, seas, and coasts. The activities of the Blue Economy, such as fishing, aquaculture, and energy, will be highlighted, as well as concepts of politics and economics (challenges, governance, growth, impact, performance, policy, and politics). The node colors associate the concepts commonly used together in the analyzed articles.

\section{Discussion}

The effect of anthropogenic activities that cause environmental degradation has been diminished due to the pause of these activities in the face of measures to contain the rapid spread of COVID-19 [70]. The impacts of the suspension of industrial activities, vehicular transport and other businesses should be part of the new challenges to be measured, as policy makers and stakeholders must also assess which blue products could also be affected by these types of stoppages and which would cause a delay in the progress of policies associated with blue growth [18].

Although several research studies have pointed out the potential for blue growth to increase seafood production through the expansion of marine and coastal aquaculture, the sector as a whole lacks policies and a clear method for benefit sharing with the community that must be considered in future planning and development of sustainable and equitable aquaculture $[52,53]$. Although it has been mentioned that progress in the development of the Blue Economy should be a joint effort between the public and private sectors, these findings show how, by accepting funding from philanthropic foundations, it has been found that governments have diminished their influence in decision making over territories and resources. Thus, there are legal and financial provisions that act as intentional and unacknowledged drivers for a monopolization and control of marine resources [71]. On 
the other hand, blended finance can be a technical solution that forms the basis for marketbased environmental governance, leaving aside the interests of coastal communities [28].

In addition, this runs the risk of becoming a development income that gets captured by the financial sector, as philanthropic organizations have long contributed to environmental conservation through non-refundable donations, but some are now beginning to adopt new profit-oriented investment strategies [71].

Establishing the comparisons in this article, in terms of meta-analytical science measurements [72], we can detail work on a generic search vector that attempts to study the Blue Economy, without the emphasis or sectoral limitations that other recently published literature has had [21,40], allowing a panoramic view of this economy type. A single database is also used, which allows a homogeneous comparison between the extracted articles-mainly Scopus articles that not indexed in JCR-WoS, given their non-homologous nature [73], establishing in this methodological aspect differences with recent bibliometric articles published on topics related to the Blue Economy [21,74]; although, with the consequent elitization of the sample, in search of defining the epistemic community and its referents, internal comparisons are achieved with a higher methodological quality.

Finally, although in all parts of the world the sea has traditionally been the engine of economic growth, research on the economic value of the Blue Economy has been limited, not including the importance of local economic data in understanding the potential of Blue Economies [13].

\section{Conclusions}

The authors show that the dialogue between local communities and the different interest groups (state, companies, and others) is fundamental for the conservation of the oceans that allows an adequate coexistence between coastal communities and different converging interests. However, there are only a few studies that allow the integration of attributes and factors that measure an adequate experience and balance between the interests of the inhabitants of coastal tourist areas and other interest groups, and that have comparable methodologies that allow for the standardization of results.

On the other hand, there is a high interest on the part of researchers to continue deepening the understanding of the phenomenon of tourism, the development of technology for obtaining ocean energy, environmental conservation, and its relationship with the territory, which demonstrates an important field of research development.

Finally, the inclusion of the objectives of the SDGs is fundamental when it comes to creating guidelines that will allow governments to lay the foundations for a Blue Economy.

Supplementary Materials: The following are available online at https:/ / www.mdpi.com/article/10 .3390/w13223234/s1, Table S1: Blue Economy savedrecs-2021-10-20T203807.357.

Author Contributions: Conceptualization, G.S.-S. and A.V.-M.; methodology, N.C.-B.; software, G.S.-S.; validation A.V.-M.; formal analysis, G.S.-S. and A.V.-M.; writing-original draft preparation, G.S.-S. and N.C.-B.; writing-review and editing, A.V.-M.; supervision, A.V.-M.; project administration, N.C.-B.; funding acquisition, G.S.-S. All authors have read and agreed to the published version of the manuscript.

Funding: The APC was partially funded by Universidad Católica de la Santísima Concepción.

Institutional Review Board Statement: Not applicable.

Informed Consent Statement: Not applicable.

Data Availability Statement: The analyzed dataset has been included as Supplementary Material.

Conflicts of Interest: The authors declare no conflict of interest.

\section{References}

1. Gunn, H.K. How Should We Build Epistemic Community? J. Specul. Philos. 2020, 34, 561-581. [CrossRef]

2. Dunlop, C. The Possible Experts: How Epistemic Communities Negotiate Barriers to Knowledge Use in Ecosystems Services Policy. Environ. Plan. C Gov. Policy 2014, 32, 208-228. [CrossRef] 
3. Shapiro, S.; Guston, D. Procedural control of the bureaucracy, peer review, and epistemic drift. J. Public Adm. Res. Theory 2007, 17, 535-551. [CrossRef]

4. Haas, P.M. Introduction: Epistemic communities and international policy coordination. Int. Organ. 1992, 46, 1-35. [CrossRef]

5. Maliniak, D.; Parajon, E.; Powers, R. Epistemic Communities and Public Support for the Paris Agreement on Climate Change. Political Res. Q. 2020. [CrossRef]

6. Mabon, L.; Shih, W.Y.; Kondo, K.; Kanekiyo, H.; Hayabuchi, Y. What is the role of epistemic communities in shaping local environmental policy? Managing environmental change through planning and greenspace in Fukuoka City, Japan. Geoforum 2019, 104, 158-169. [CrossRef]

7. Miller, H.; Fox, C. The Epistemic Community. Adm. Soc. 2001, 32, 668-685. [CrossRef]

8. Smirnova, M.; Yachin, E. From expert to epistemic communities: On the transformation of institutional frames of power in the modern world. J. Soc. Sci. Res. 2014, 5, 649-657. [CrossRef]

9. Lee, K.H.; Noh, J.; Khim, J.S. The Blue Economy and the United Nations' sustainable development goals: Challenges and opportunities. Environ. Int. 2020, 137, 105528. [CrossRef] [PubMed]

10. Graziano, M.; Alexander, K.A.; Liesch, M.; Lema, E.; Torres, J.A. Understanding an emerging economic discourse through regional analysis: Blue economy clusters in the US Great Lakes basin. Appl. Geogr. 2019, 105, 111-123. [CrossRef]

11. European Commission. The EU Blue Economy Report 2021; Publications Office of the European Union: Luxembourg, 2021. Available online: https:/ / op.europa.eu/s/ub7x (accessed on 8 November 2021).

12. Obura, D.O. Getting to 2030-Scaling effort to ambition through a narrative model of the SDGs. Mar. Policy 2020, $117,103973$. [CrossRef]

13. Qi, X.F.; Zhao, B.X.; Zhang, J.H.; Xiao, W.W. The drawing of a national blue product space and its evolution. Mar. Policy 2020, 112, 103773. [CrossRef]

14. Choudhary, P.; Subhash, G.V.; Khade, M.; Savant, S.; Musale, A.; Kumar, G.R.; Chelliah, M.S.; Dasgupta, S. Empowering blue economy: From underrated ecosystem to sustainable industry. J. Environ. Manag. 2021, 291, 112697. [CrossRef]

15. Katila, J.; Ala-Rami, K.; Repka, S.; Rendon, E.; Torronen, J. Defining and quantifying the sea-based economy to support regional blue growth strategies-Case Gulf of Bothnia. Mar. Policy 2019, 100, 215-225. [CrossRef]

16. Ahmed, N.; Thompson, S. The blue dimensions of aquaculture: A global synthesis. Sci. Total Environ. 2019, 652, 851-861. [CrossRef]

17. Van den Burg, S.W.K.; Aguilar-Manjarrez, J.; Jenness, J.; Torrie, M. Assessment of the geographical potential for co-use of marine space, based on operational boundaries for Blue Growth sectors. Mar. Policy 2019, 100, 43-57. [CrossRef]

18. Qi, X.F.; Xiao, W.W.; Xiang, X.M. The spatial pattern of the blue product development of nations: An empirical analysis based on product space theory. Ocean Coast. Manag. 2021, 207, 105596. [CrossRef]

19. Aryai, V.; Abbassi, R.; Abdussamie, N.; Salehi, F.; Garaniya, V.; Asadnia, M.; Baksh, A.A.; Penesis, I.; Karampour, H.; Draper, S.; et al. Reliability of multi-purpose offshore-facilities: Present status and future direction in Australia. Process Saf. Environ. Protect. 2021, 148, 437-461. [CrossRef]

20. Jones, D.O.; Durden, J.M.; Murphy, K.; Gjerde, K.M.; Gebicka, A.; Colaco, A.; Morato, T.; Cuvelier, D.; Billett, D.S. Existing environmental management approaches relevant to deep-sea mining. Mar. Policy 2019, 103, 172-181. [CrossRef]

21. Kabil, M.; Priatmoko, S.; Magda, R.; David, L.D. Blue Economy and Coastal Tourism: A Comprehensive Visualization Bibliometric Analysis. Sustainability 2021, 13, 3650. [CrossRef]

22. Bethel, B.J.; Buravleva, Y.; Tang, D.C. Blue Economy and Blue Activities: Opportunities, Challenges, and Recommendations for The Bahamas. Water 2021, 13, 1399. [CrossRef]

23. Karani, P.; Failler, P. Comparative coastal and marine tourism, climate change, and the blue economy in African Large Marine. Ecosystems. Environ. Dev. 2020, 36, 100573. [CrossRef]

24. Alam, M.W.; Xu, X.M.; Ahamed, R.; Mozumder, M.M.H.; Schneider, P. Ocean governance in Bangladesh: Necessities to implement structure, policy guidelines, and actions for ocean and coastal management. Reg. Stud. Mar. Sci. 2021, 45, 101822. [CrossRef]

25. Vazquez, R.M.M.; Garcia, J.M.; Valenciano, J.D. Analysis and Trends of Global Research on Nautical, Maritime and Marine Tourism. J. Mar. Sci. Eng. 2021, 9, 93. [CrossRef]

26. Cisneros-Montemayor, A.M.; Townsel, A.; Gonzales, C.M.; Haas, A.R.; Navarro-Holm, E.E.; Salorio-Zuniga, T.; Johnson, A.F. Nature-based marine tourism in the Gulf of California and Baja California Peninsula: Economic benefits and key species. Nat. Resour. Forum. 2020, 44, 111-128. [CrossRef]

27. Bhattacharya, P.; Dash, A.K. Determinants of blue economy in Asia-Pacific island countries: A study of tourism and fisheries sectors. Ocean Coast. Manag. 2021, 211, 105774. [CrossRef]

28. Christiansen, J. Fixing fictions through blended finance: The entrepreneurial ensemble and risk interpretation in the Blue Economy. Geoforum 2021, 120, 93-102. [CrossRef]

29. Boschen-Rose, R.E.; Ferreira, M.A.; Johnson, D.E.; Gianni, M. Engaging with Industry to Spur Blue Growth. J. Coast. Res. 2020, 95, 835-839. [CrossRef]

30. Hasselstrom, L.; Grondahl, F. Payments for nutrient uptake in the blue bioeconomy-When to be careful and when to go for it. Mar. Pollut. Bull. 2021, 167, 112321. [CrossRef]

31. Chen, T.A.; Shih, Y.C. Blue economy based on local DNA in Taiwan: Marine regional revitalisation under the collaboration of the local and central government. Mar. Policy 2021, 132, 104668. [CrossRef] 
32. Saldarriaga-Hernandez, S.; Melchor-Martinez, E.M.; Carrillo-Nieves, D.; Parra-Saldivar, R.; Iqbal, H.M. Seasonal char-acterization and quantification of biomolecules from sargassum collected from Mexican Caribbean coast-A preliminary study as a step forward to blue economy. J. Environ. Manag. 2021, 298, 113507. [CrossRef]

33. Seisdedos, M.R.; Carrasco, P.F. Port Projects in Blue Economy: Port of Motril-Granada. J. Coast. Res. 2020, 95, 940-944. [CrossRef]

34. Campbell, L.M.; Fairbanks, L.; Murray, G.; Stoll, J.S.; D’Anna, L.; Bingham, J. From Blue Economy to Blue Communities: Reori-enting aquaculture expansion for community wellbeing. Mar. Policy 2021, 124, 104361. [CrossRef]

35. Bennett, N.J.; Blythe, J.; White, C.S.; Campero, C. Blue growth and blue justice: Ten risks and solutions for the ocean econ-omy. Mar. Policy 2021, 125, 104387. [CrossRef]

36. Wiber, M.G.; Mather, C.; Knott, C.; Gomez, M.A. Regulating the Blue Economy? Challenges to an effective Canadian aqua-culture act. Mar. Policy 2021, 131, 104700. [CrossRef]

37. Chen, J.L.; Hsu, K.; Chuang, C.T. How do fishery resources enhance the development of coastal fishing communities: Lessons learned from a community-based sea farming project in Taiwan. Ocean Coast. Manag. 2020, 184, 105015. [CrossRef]

38. Alqattan, M.E.; Gray, T.S.; Stead, S.M. The illegal, unreported and unregulated fishing in Kuwait: Problems and solutions. Mar. Policy 2020, 116, 103775. [CrossRef]

39. Ibabe, A.; Borrell, Y.J.; Knobelspiess, S.; Dopico, E. Perspectives on the marine environment and biodiversity in recreational ports: The marina of Gijon as a case study. Mar. Pollut. Bull. 2020, 160, 111645. [CrossRef]

40. Garcia, A.A. Relationship between Blue Economy, Cruise Tourism, and Urban Regeneration: Case Study of Olbia, Sardinia. J. Urban Plan. Dev. 2021, 147, 05021029. [CrossRef]

41. Dimopoulos, D.; Queiros, D.; van Zyl, C. Sinking deeper: The most significant risks impacting the dive tourism industry in the East African Marine Ecoregion. Ocean Coast. Manag. 2019, 181, 104897. [CrossRef]

42. Neto, G.C.; da Silva, P.C.; Tucci, H.N.; Amorim, M. Reuse of water and materials as a cleaner production practice in the textile industry contributing to blue economy. J. Clean Prod. 2021, 305, 127075. [CrossRef]

43. Tucci, H.N.; Neto, G.C.; Rodrigues, F.L.; Giannetti, B.F.; Almeida, C.M. Six sigma with the blue economy fundamentals to assess the economic and environmental performance in the aircraft refueling process. Renew. Sustain. Energy Rev. 2021, 150, 111424. [CrossRef]

44. Janes, H.; Carnell, P.; Young, M.; Ierodiaconou, D.; Jenkins, G.P.; Hamer, P.; Zu Ermgassen, P.S.; Gair, J.R.; Macreadie, P.I. Seagrass valuation from fish abundance, biomass and recreational catch. Ecol. Indic. 2021, 130, 108097. [CrossRef]

45. Sridharan, S.; Kumar, M.; Bolan, N.S.; Singh, L.; Kumar, S.; Kumar, R.; You, S.M. Are microplastics destabilizing the global network of terrestrial and aquatic ecosystem services? Environ. Res. 2021, 198, 111243. [CrossRef] [PubMed]

46. Hemer, M.A.; Manasseh, R.; McInnes, K.L.; Penesis, I.; Pitman, T. Perspectives on a way forward for ocean renewable energy in Australia. Renew. Energy 2018, 127, 733-745. [CrossRef]

47. Wei, Y.Z.; Zou, Q.P.; Lin, X.H. Evolution of price policy for offshore wind energy in China: Trilemma of capacity, price and subsidy. Renew. Sustain. Energy Rev. 2021, 136, 110366. [CrossRef]

48. Sedlar, D.K.; Vulin, D.; Krajacic, G.; Jukic, L. Offshore gas production infrastructure reutilisation for blue energy production. Renew. Sustain. Energy Rev. 2019, 108, 159-174. [CrossRef]

49. Dillon, T.; Maurer, B.; Lawson, M.; Jenne, D.S.; Manalang, D.; Baca, E.; Polagye, B. Cost-optimal wave-powered persistent oceanographic observation. Renew. Energy 2022, 181, 504-521. [CrossRef]

50. Oikonomou, C.L.; Gomes, R.P.; Gato, L.M. Unveiling the potential of using a spar-buoy oscillating-water-column wave energy converter for low-power stand-alone applications. Appl. Energy 2021, 292, 116835. [CrossRef]

51. Hildebrand, T.; Fischer, C.; Relano, V.; Gorman, R.; Stevens, C. Cost-Benefit Analysis of a Hybrid Biophysical Approach to Wave Energy Extraction: Bio-Oscillator. Front. Mar. Sci. 2021, 8, 393. [CrossRef]

52. Brugere, C.; Troell, M.; Eriksson, H. More than fish: Policy coherence and benefit sharing as necessary conditions for equi-table aquaculture development. Mar. Policy 2021, 123, 104271. [CrossRef]

53. Soininen, N.; Belinskij, A.; Simala, J.; Kortet, R. Too important to fail? Evaluating legal adaptive capacity for increasing coastal and marine aquaculture production in EU-Finland. Mar. Policy 2019, 110, 103498. [CrossRef]

54. Cheng, Y.T.; Tseng, Y.C.; Iwaki, Y.; Huang, M.C. Sustainable food security in Small Island Developing States (SIDS): A case of Horticulture project in Marshall Islands. Mar. Policy 2021, 128, 104378. [CrossRef]

55. Newton, M.J.; Farrelly, T.A.; Sinner, J. Discourse, agency, and social license to operate in New Zealand's marine economy. Ecol. Soc. 2020, 25. [CrossRef]

56. Fondo, E.N.; Ogutu, B. Sustainable crab fishery for Blue Economy in Kenya. Aquat. Ecosyst. Health Manag. 2021, 24, 21-26. [CrossRef]

57. Rubilar, T.; Cardozo, D. Blue Growth: Sea Urchin Sustainable Aquaculture, Innovative Approaches. Rev. Biol. Trop. 2021, 69, 474-486. [CrossRef]

58. Mohsin, M.; Mu, Y.T.; Mehak, A.; Memon, A.M.; Noman, M.; Nazir, K. Aquaculture in Pakistan: Status, Opportunities and Chal-lenges. Indian J. Geo-Mar. Sci. 2017, 46, 1872-1878.

59. Daly, J.; Knott, C.; Keogh, P.; Singh, G.G. Changing climates in a blue economy: Assessing the climate-responsiveness of Canadian fisheries and oceans policy. Mar. Policy 2021, 131, 104623. [CrossRef]

60. Zhang, X.Y.; Zhu, F.Y.; Li, Y. Marine Resources Accounting: A Diversification of Subject-Based Study. J. Coast. Res. 2020, 106, 5-8. [CrossRef] 
61. Frades, J.L.; Barba, J.G.; Negro, V.; Martin-Anton, M.; Soriano, J. Blue Economy: Compatibility between the Increasing Off-shore Wind Technology and the Achievement of the SDG. J. Coast. Res. 2020, 95, 1490-1494. [CrossRef]

62. Voyer, M.; Farmery, A.K.; Kajlich, L.; Vachette, A.; Quirk, G. Assessing policy coherence and coordination in the sustainable development of a Blue Economy. A case study from Timor Leste. Ocean Coast. Manag. 2020, 192, 105187. [CrossRef]

63. Potts, T.; Niewiadomski, P.; Prager, K. The Green Economy Research Centre-positioning geographical research in Aber-deen to address the challenges of green economy transitions. Scott. Geogr. J. 2019, 135, 356-370. [CrossRef]

64. Vega-Muñoz, A.; Arjona-Fuentes, J.M. Social Networks and Graph Theory in the Search for Distant Knowledge in the Field of Industrial Engineering. In Advanced Applications of Graph Theory in Modern Society; Pal, M., Samanta, S., Pal, A., Eds.; IGI-Global: Hershey, PA, USA, 2020; pp. 397-418. [CrossRef]

65. Price, D. A general theory of bibliometric and other cumulative advantage processes. J. Assoc. Inf. Sci. 1976, 27, 292-306. [CrossRef]

66. Dobrov, G.M.; Randolph, R.H.; Rauch, W.D. New options for team research via international computer networks. Scientometrics 1979, 1, 387-404. [CrossRef]

67. Bulik, S. Book use as a Bradford-Zipf Phenomenon. Coll. Res. Libr. 1978, 39, 215-219. [CrossRef]

68. Lotka, A.J. The frequency distribution of scientific productivity. J. Wash. Acad. Sci. 1926, 16, 317-321.

69. Van Eck, N.J.; Waltman, L. Software survey: VOSviewer, a computer program for bibliometric mapping. Scientometrics 2010, 84, 523-538. [CrossRef]

70. Robin, R.S.; Purvaja, R.; Ganguly, D.; Hariharan, G.; Paneerselvam, A.; Sundari, R.T.; Karthik, R.; Neethu, C.S.; Sara-vanakumar C.; Semanti, P.; et al. COVID-19 restrictions and their influences on ambient air, surface water and plastic waste in a coastal megacity, Chennai, India. Mar. Pollut. Bull. 2021, 171, 112739. [CrossRef]

71. Mallin, M.A.; Stolz, D.C.; Thompson, B.S.; Barbesgaard, M. In oceans we trust: Conservation, philanthropy, and the political economy of the Phoenix Islands Protected Area. Mar. Policy 2019, 107, 103421. [CrossRef]

72. Kullenberg, C.; Kasperowski, D. What is citizen science?-A scientometric meta-analysis. PLoS ONE 2016, 11, e0147152. [CrossRef]

73. Chadegani, A.A.; Salehi, H.; Yunus, M.M.; Farhadi, H.; Fooladi, M.; Farhadi, M.; Ebrahim, N.A. A comparison between two main academic literature collections: Web of science and scopus databases. Asian Soc. Sci. 2013, 9, 18-26. [CrossRef]

74. Paredes-Coral, E.; Mokos, M.; Vanreusel, A.; Deprez, T. Mapping Global Research on Ocean Literacy: Implications for Science, Policy, and the Blue Economy. Front. Mar. Sci. 2021, 8, 648492. [CrossRef] 